\title{
Transforming the Future of Infrastructure through Smarter Information
}

Proceedings of the International

Conference on Smart Infrastructure and

Construction, 27-29 June 2016

Edited by

RJ Mair, K Soga, Y Jin, AK Parlikad and

JM Schooling 


\section{Organising Committee:}

Professor Lord Mair

Professor Kenichi Soga

Dr Ying Jin

Dr Ajith Parlikad

Dr Jennifer Schooling

\section{Supported by:}

Dr Krishna Kumar

Samantha Archetti

Tianlei Wu

Published by ICE Publishing, One Great George Street, Westminster, London SW1P 3AA.

Full details of ICE Publishing sales representatives and distributors can be found at:

www.icebookshop.com/bookshop_contact.asp

Other CSIC titles from ICE Publishing:

Bridge Monitoring: A practical guide

C. Middleton, P. Fidler, P. Vardanega. ISBN 978-0-7277-6059-3

Distributed Fibre Optic Strain Sensing for Monitoring Civil Infrastructure: A practical guide

C. Kechavarzi, K. Soga, M. Elshafie, R.J. Mair, N. de Battista, L. Pelecanos. ISBN 978-0-7277-6055-5

Whole-Life Value-Based Decision-Making in Asset Management

R. Srinivasan, A. Parlikad. ISBN 978-0-7277-6061-6

Wireless Sensor Networks for Civil Infrastructure Monitoring: A best practice guide

D. Rodenas-Herráiz, K. Soga, P. Fidler, N. de Battista. ISBN 978-0-7277-6151-4

A catalogue record for this book is available from the British Library

ISBN 978-0-7277-6127-9

(C) The authors and ICE Publishing 2016

ICE Publishing is a division of Thomas Telford Ltd, a wholly-owned subsidiary of the Institution of Civil Engineers (ICE).

All rights, including translation, reserved. Except as permitted by the Copyright, Designs and Patents Act 1988, no part of this publication may be reproduced, stored in a retrieval system or transmitted in any form or by any means, electronic, mechanical, photocopying or otherwise, without the prior written permission of the Publisher, ICE Publishing, One Great George Street, Westminster, London SW1P 3AA.

This book is published on the understanding that the author is solely responsible for the statements made and opinions expressed in it and that its publication does not necessarily imply that such statements and/or opinions are or reflect the views or opinions of the publishers. Whilst every effort has been made to ensure that the statements made and the opinions expressed in this publication provide a safe and accurate guide, no liability or responsibility can be accepted in this respect by the author or publishers.

Whilst every reasonable effort has been undertaken by the author and the publisher to acknowledge copyright on material reproduced, if there has been an oversight please contact the publisher and we will endeavour to correct this upon a reprint.

Commissioning Editor: Gavin Jamieson

Production Editor: Rebecca Norris

Market Development Executive: Elizabeth Hobson

Typeset by Manila Typesetting Company

Printed and bound in Great Britain by TJ International Ltd, Padstow 


\section{Contents}

Preface

\section{SECTION A: SENSORS AND DATA ANALYSIS}

\section{Fibre optics sensing - applications}

Distributed measurements with optical sensors in the EDF group: experience feedback and perspectives

Y.-L. BECK, F. MARTINOT, S. DESFORGES, E. BUCHOUD AND J.M. HENAULT

Distributed fibre optic sensors for the purposes of structural performance monitoring

A. BRAULT, N.A. HOULT, I. TRUDEAU, T. GREENOUGH AND B. CHARNISH

Development of self-sensing concrete sleepers for next-generation rail infrastructure

Distributed fibre optic sensors for measuring strain and temperature of cast-in-situ concrete test piles N. DE BATTISTA, C. KECHAVARZI, H. SEO, K. SOGA AND S. PENNINGTON

Distributed fibre optic long-term monitoring of concrete-lined tunnel section TT10 at CERN V. DI MURRO, L. PELECANOS, K. SOGA, C. KECHAVARZI, R.F. MORTON AND L. SCIBILE

Distributed monitoring of buried pipelines with Brillouin fiber optic sensors

X. FENG, X.W. ZHANG, W.J. WU, X.Y. LI, X. LI AND J. ZHOU

Study on the identification of dynamic behavior of beam structure by random access strain histories of Brillouin-based optical fiber sensor

M. IMAI AND S. MATSUURA

Condition monitoring of railway tracks and vehicles using fibre optic sensing techniques

W. LIENHART, C. WIESMEYR, R. WAGNER, F. KLUG, M. LITZENBERGER AND D. MAICZ

Application of long-term structural monitoring data to bridge operations: a case study of a fiber-optic monitoring in a prestressed concrete bridge

M. NISHIO, J. XU AND J. MIZUTANI

Distributed fibre-optic monitoring of tension piles under a basement excavation at the V\&A Museum in London

L. PELECANOS, K. SOGA, S. HARDY, A. BLAIR, K. CARTER AND D. PATEL

Fibre-optic distributed acoustic and vibration sensing for monitoring of industrial plants and installations

P. ROHWETTER, R. EISERMANN, S. GROßWIG AND K. KREBBER

Optical fiber sensors for subsea and topside asset integrity monitoring applications

Fiber-optic sensors based on FBGs with increased sensitivity difference embedded in polymer composite material for separate strain and temperature measurements

V.V. SHISHKIN, V.S. TERENTYEV, D.S. KHARENKO, A.V. DOSTOVALOV, A.A. WOLF, V.A. SIMONOV, M.YU. FEDOTOV, A.M. SHIENOK, I.S. SHELEMBA AND S.A. BABIN

Vibration and deformation monitoring of a long-span rigid-frame bridge with distributed long-gauge sensors Y.D. TIAN AND J. ZHANG

The evaluation of bridges by distributed FBG sensors 
Fibre optics sensing - theory

Applications and prospects for distributed sensing using polymer optical fibres

S. LIEHR AND K. KREBBER

Iterative filtering for time-frequency localised pulse optimisation in STFT-BOTDR

99

L. LUO, B. LI, Y. YU, X. XU, J. YAN AND K. SOGA

Characterization on the distributed fibre optic sensors using a newly developed calibration system

105

Y. MEI, X. XU, J. YAN AND K. SOGA

Industry challenges on resolution, linearity and optical budget of high-accuracy distributed Brillouin sensing

111

N. NÖTHER AND M. KRCMAR

Measurement error modification of linear non-uniform strain for BOTDA and a case study

117

J. XU, Y. DONG AND H. LI

Multiple windows algorithm for event detection in STFT-BOTDR

Y. YU, L. LUO, B. LI, J. YAN AND K. SOGA

\section{Wireless sensor network systems}

Compressive sensing-based wireless sensors and sensor networks for structural health monitoring

Y. BAO AND H. LI

Design of a wireless smart sensor node for fatigue assessment of welded joints

H.P. DING

Validation of wireless sensing technology densely instrumented on a full-scale concrete frame structure

X. DONG, X. LIU, T. WRIGHT, Y. WANG AND R. DESROCHES

Development of RTOS-based wireless SHM system: benefits in applications

Y.G. FU, K.A. MECHITOV, V. HOSKERE AND B.F. SPENCER, JR.

Low power DSP with wireless monitoring for civil constructions

V. KUMAR, J. YAN, X. XU, Y. QIAN AND K. SOGA

Wireless remote condition monitoring opens new monitoring applications in railway tunnel deformation and trackbed

S. MADDISON AND B. SMITH

Dynamic characteristics of a damaged pedestrian overpass measured by wireless sensor array

Y. MIYAMORI, T. KADOTA, Y. ZHANG AND S. MIKAMI

Wireless sensor network based pipeline failure detection system using non-intrusive relative pressure and differential temperature measurements

A.M. SADEGHIOON, N. METJE, D.N. CHAPMAN AND C.J. ANTHONY

Development and field experiment of routing-free multi-hop wireless sensor networks for structural monitoring

M. SUZUKI, K. JINNO, Y. TASHIRO, Y. KATSUMATA, C.H. LIAO, T. NAGAYAMA, N. MAKIHATA,

M. TAKAHASHI, M. IEIRI AND H. MORIKAWA

Multi-point monitoring of unstable slope with tilt sensors

T. UCHIMURA, S.N. TAO, I. TOWHATA, L. WANG, L. SU, S. NISHIE, H. YAMAGUCHI AND I. SEKO

Wireless sensing on shield tunnels in Shanghai

191

F. WANG, H.W. HUANG, B. HE, Y. WU, H. SHAO AND H.M. WU

iv 
Application of a wireless mobile system for real-time bridge scour monitoring

M.C. WANG, W.T. CHOU, T.K. LIN, K.C. LU AND K.C. CHANG

Monitoring on the performance of temporary props using wireless strain sensing

X.M. XU, P.R.A. FIDLER, D. RODENAS-HERRAIZ, W. LI, V. KUMAR, J. BIRKS, J. YAN AND K. SOGA

Wireless sensor monitoring of Paddington Station Box Corner

X.M. XU, S. NAWAZ, P. FIDLER, D. RODENAS-HERRAIZ, J. YAN AND K. SOGA

Design of a wireless structural vibration control experimental system based on wireless sensor networks

Autonomous evaluation of human annoyance rate induced by subway trains using high-sensitivity wireless smart sensors

W. ZHANG, K. SUN, H. DING, R.E. KIM AND B.F. SPENCER, JR.

\section{New sensor systems}

Field monitoring of piling effects on a nearby masonry vault using distributed sensing

S. ACIKGOZ, L. PELECANOS, G. GIARDINA AND K. SOGA

Structural behavior sensing using small sized self-propelled inspection robot

A. AKUTSU, E. SASAKI AND K. TAKEYA

Ultrasonic sensor system for automatic depth measurement of surface opening cracks in concrete by means of a robotic arm

L. BELSITO, L. MASINI, M. SANMARTIN, K. LOUPOS AND A. RONCAGLIA

Bridge scour monitoring system development

K.-C. CHANG, Y.-B. LIN, M.-H. GU AND B.-H. LEE

A sensor system for real-time bridge scouring monitoring

S.-Y. CHEN, Y.-J. HSIEH, C.-C. YANG, F.-C. CHENG, Y.-D. HUANG, J.-J. CHUE, C.-T. KUO, C.-M. WU

AND C.-M. HUANG

Understanding the advantages of satellite Earth Observation as a surveying tool for infrastructure monitoring

M. DE FARAGO, G. COOKSLEY, M. COSTANTINI, F. MINATI, F. TRILLO, L. PAGLIA AND J. GATES

Fundamental investigation on applicability of Piezofilm Sensor in sensing low-frequency structural response of bridges

C.V. DUNG AND E. SASAKI

Smartphones equipped with android application software for structural health monitoring

K. FANG, J.D. TIAN, D.Y. ZHANG AND H. LI

Smart Automation System dedicated to Infrastructure and Construction

B. FAZZARI, A. STELLA, G. NAVARRA AND F. LO IACONO

Tri-band ground penetrating radar for subsurface structural condition assessments and utility mapping

D. HUSTON, T. XIA, Y. ZHANG, T. FAN, J. RAZINGER AND D. BURNS

Sensing for smart infrastructure: prospective engineering applications

A. KLAR, E. LEVENBERG, M. TUR AND A. ZADOK

Damage detection of a reinforced concrete column under simulated pseudo-dynamic loading using smart aggregates

Q. KONG, R.H. ROBERT, P. SILVA, G. SONG AND Y.L. MO 
Detection of tensile force loss in a pre-stressing strand using coil impedance measurement

J. LEE, J. KIM AND H. SOHN

Integrated ROBOTIC solution for tunnel structural evaluation and characterization - ROBO-SPECT EC project

K. LOUPOS, A. AMDITIS, A. DOULAMIS, P. CHROBOCINSKI, J. VICTORES, M. WIETEK, P. PANETSOS,

A. RONCAGLIA, S. CAMARINOPOULOS, V. KALLIDROMITIS, D. BAIRAKTARIS, N. KOMODAKIS AND

R. LOPEZ

Sensing capability enhancement of multifunctional carbon fiber-sprayed FRP composites fabricated with CNT-modified epoxy

I.W. NAM AND H.K. LEE

Nano-carbon cement based sensors for smart structures

G. NOISEUX-LAUZE, J. ORELLANA AND G. AKHRAS

Surface deformation evaluation of sandwich plate with aluminum foam cores under high speed impact loading based on stereovision

B. SHAN, B. ZHANG AND Y. YAN

A quantitative guided wave-based damage monitoring method for complex composite structures

Z. WU, K. LIU, S. MA AND Y. ZHENG

Monitoring system by vibration power generation

Y. YOSHIDA, Y. KOBAYASHI AND T. UCHIMURA

Smartphone based cloud-SHM and its applications

X. ZHAO, R. HAN, Y. YU, H. LIU, Y. DING, M. LI AND J. OU

Dynamic measurements and analysis

Characterization of a traveling object with an underground cluster of accelerometers

O. DRORI AND E. LEVENBERG

An observability analysis for profile estimation through vehicle response measurement

T. JOTHI SARAVANAN, Z. BOYU, D. SU AND T. NAGAYAMA

Large-scale road surface evaluation using dynamic responses of commercial vehicles

N. MAKIHATA, B. ZHAO, M. TOYODA, M. TAKAHASHI, M. IEIRI AND T. NAGAYAMA

A. ROY, A.(D.) GHOSH AND B. BASU

System for evaluating fatigue environment of steel girder bridge based on acceleration measurements

H. SEKIYA, C. MIKI, O. MARUYAMA AND T. KINOMOTO

Traffic volume estimation and load capacity evaluation using dynamic responses acquired in the structural health monitoring of a cable-stayed bridge

K. WATTANA AND M. NISHIO

Seismic damage monitoring of high concrete dams with embedded PZT sensor network

\section{Data analysis - bridges}

Mechanical equivalent of logical inference: application to structural health monitoring problems 
Wind-induced variation of structural parameters of cable-stayed bridge

T.C. HUYNH, S.H. CHOI AND J.T. KIM

Finite element model updating based on a Kriging surrogate model for bridge performance evaluation

H.Y. JUNG, J.H. LEE, S.S. JIN AND H.J. JUNG

Smart structural health monitoring system for damage identification in bridges using relative wavelet entropy

M. MORAVVEJ, M. EL-BADRY AND P. JOULANI

Clarification of cross-sectional vibration characteristics for damage identification of belt conveyor support structure

S. RANA, T. NAGAYAMA, K. HISAZUMI AND T. TOMINAGA

Detection of uniform structural temperature distributions for a temperature based method of structural health monitoring

J. REILLY, H. ABDEL-JABER, M. YARNOLD AND B. GLISIC

A wavelet-energy based damage identification method for steel bridges

H. WANG, M. NOORI AND J. ZHANG

Effect of vertical excitation on horizontal performance of sloped rolling-type seismic isolation bearings

\section{Data analysis - buildings}

Analytical simulation on seismic mitigation of raised floor systems using sloped rolling-type isolation devices and magnetorheological dampers

P.-C. CHEN AND S.-J. WANG

A new and efficient method for the determination of Output Frequency Response Function of nonlinear vibration systems

N.N.L. NIK IBRAHIM AND Z.Q. LANG

Shaking table test of seismic bracings used in piping systems

X.Q. NIN, J.W. DAI, D.Z. WANG, Y.Q. YANG AND W. BAI

Effects of joint rotational stiffness on structural responses of multi-story modular buildings A.J. STYLES, F.J. LUO, Y. BAI AND J.B. MURRAY-PARKES

Stethoscope-like smart sensing for system identification of building frames

I. TAKEWAKI AND K. FUJITA

Safety evaluation of complex civil structures using structural health monitoring

J. TENG, W. LU AND Y. CUI

Response enhancement of a 32-story building structure using two types of track nonlinear energy sinks J. WANG, X. LU, N.E. WIERSCHEM AND B.F. SPENCER, JR.

\section{Data analysis - geotechnical structures}

Structural health monitoring system of railway bridge substructures utilizing soundness diagnosis index correlated with natural frequency 
An event-adaptive control mechanism of the tunnel monitoring system based on the information granularity

G. LI, B. HE AND H. HUANG

Strain monitoring and analysis of a steel pipe during horizontal directional crossing

499

S. LI AND X. LI

Performance based design for the Crossrail Liverpool Street Station

505

H.L. LIEW, I. FAROOQ, Y.S. HSU AND A.S. O’BRIEN

Bayesian updating of subsurface spatial correlation through monitoring of infrastructure and building developments

M.K. LO AND Y.F. LEUNG

The early detection method for embankment collapse using acceleration data

S. RYUO, A. HADA, N. IWASAWA, T. KAWAMURA, M. NOZUE AND K. KAWASAKI

523

Study on mechanics performance of prefabricated trench block

Y. ZOU, C. WANG, L. ZHENG, X. CAI AND X. FENG

\section{SECTION B: ASSETS}

Asset information management

Bridge data - what do we collect and how do we use it?

J. BENNETTS, P.J. VARDANEGA, C.A. TAYLOR AND S.R. DENTON

Modelling, management, and visualisation of structural performance monitoring data on BIM

J.M. DAVILA DELGADO, I. BRILAKIS AND C. MIDDLETON

Green2.0: Socio-technical analytics of green buildings

T. EL-DIRABY, T.F. KRIJNEN AND M. PAPAGELIS

Information future-proofing assessment for infrastructure assets

T. MASOOD, G. YILMAZ, D.C. MCFARLANE, A.K. PARLIKAD, K. HARWOOD AND R. DUNN

The Singapore cyber-civil-infrastructure project

I.F.C. SMITH AND R. PASQUIER

Big visual data analytics for damage classification in civil engineering

C.M. YEUM, S.J. DYKE, J. RAMIREZ AND B. BENES

\section{Deterioration modelling}

Failure assessment of underground tunnels

C.Q. LI, D.J. ROBERT, M. MAHMOODIAN AND J. DAUTH

Long-term behaviour of support elements in tunnelling - Results of investigations in several thirty year old tunnels

S. LORENZ AND R. GALLER

Grading-based deterioration models for future performance predictions of coastal flood defences

M.B. MEHRABANI AND H.-P. CHEN

viii 
Water infiltration estimation in tunnels: with reference to the Melbourne underground

Y.Q. TAN, J.V. SMITH, C.Q. LI AND J. DAUTH

Stochastic modelling of lifecycle delamination damage: evolution of composite blades of wind turbines

C. ZHANG, H.P. CHEN AND T.L. HUANG

Simulating the degradation and maintenance effects on an integrated urban transport infrastructure system

\section{Infrastructure resilience}

Flexible street lighting solutions for traffic demand uncertainty

W. FAWCETT, I. ROBLES URQUILO, S. PERALES, M. HUGHES AND M. RODRIGUEZ FERNANDEZ

Future-proofing assessment of infrastructure assets

T. MASOOD, D.C. MCFARLANE, J. SCHOOLING, A. FIELDING AND J. DOWNES

Assessment of infrastructure resilience in developing countries: a case study of water infrastructure in the 2015 Nepalese earthquake

H. NAZARNIA, A. MOSTAFAVI, N. PRADHANANGA, E. GANAPATI AND R.R. KHANAL

Vulnerability analysis of hydrological infrastructure to flooding in coastal cities - a graph theory approach R.I. OGIE, T. HOLDERNESS, S. DUNN AND E. TURPIN

Conflation of data sources for the identification of residual ground related hazards and resilience planning for the Strategic Road Network of England

C.M. POWER, D. WRIGHT, J. MIAN AND D. PATTERSON

Quantifying recovery for structures incorporating control

A. WILBEE, F. PENA, S.J. DYKE, I. BILIONIS AND P. PANDITA

Whole life cost and value

What should future design standards in the construction industry look like? The need for new value propositions

M. ANGELINO, C. TAYLOR AND S.R. DENTON

Development of resource-efficient tunneling technologies - Results of the European research project

DRAGON

R. GALLER

Cyber physical simulation of energy smart communities

A. GHOFRANI, F. FARZAN, J. SWARTZ, K. MAHANI, N. BALSAMI, P. ANSARI AND M.A. JAFARI

Sustainable asset management for utility streetworks

A. HOJJATI, I. JEFFERSON, N. METJE AND C.D.F. ROGERS

Risk-cost optimised maintenance strategy for tunnel structures

C.-Q. LI, H. BAJI, M. MAHMOODIAN AND W. YANG

Testing a PPP performance evaluation framework

Consequence-based management of North American railroad bridge networks enabled by wireless smart sensors

F. MOREU, B.F. SPENCER, JR., D.A. FOUTCH AND S. SCOLA 
An explorative study to unveil the interdependency of public housing related infrastructure assets in Hong Kong

S.T. NG, C. ZHONG AND F.J. XU

Whole life costing of infrastructure investment: economic and social infrastructure projects in Australia

M. REGAN, P. LOVE AND J. SMITH

Critical risk factors in construction projects: perspective of contractors in South Africa

B.Y. RENAULT AND J.N. AGUMBA

Value based maintenance prioritization for a portfolio of bridges

R. SRINIVASAN AND A.K. PARLIKAD

How smart sensoring improve tunnel resilience: from theoretical model to future application

D.M. ZHANG, H.W. HUANG, Q.F. HU AND Y.J. ZHANG

\section{SECTION C: CITIES AND URBAN INFRASTRUCTURE}

\section{Cities}

A dependency network description of building information models

K. AL SAYED, M. BEW AND A. PENN

An operational strategy to increase average door-to-door speeds of metro systems in megalopoleis

M. BLUMENFELD, C. ROBERTS AND F. SCHMID

Understanding traveller decision making - a crowd sourced big data analysis of the London Travel Demand Survey

G. CASEY, K. SOGA, E. SILVA AND P. GUTHRIE

Employing a system-of-systems approach to water management in the shale gas value chain

A. GUO, Z. LIU AND H. LI

Assessing the discrepancies between recorded and commonly assumed journey times in London

T. HILLEL, P. GUTHRIE, M. ELSHAFIE AND Y. JIN

A methodology to estimate losses in level of service for urban infrastructure networks

C. KIELHAUSER, N. LETHANH AND B.T. ADEY

Monitoring city-scale land use development using new online sources - the case of Beijing 


\section{Preface}

The International Conference on Smart Infrastructure and Construction (ICSIC), held in Cambridge from 27-29 June 2016, brought together world-leading academics and practitioners from the fields of infrastructure planning, asset management and infrastructure sensing and monitoring.

These Proceedings bring together the papers presented at the conference, providing inter-disciplinary insights into how smarter information leads to rapid, improved evidence-based decision making. The papers address many topics relating to smart infrastructure and construction, including the persistent barriers to industry integration of innovation and the development of novel, proactive solutions to infrastructure and construction challenges.

The papers were presented in three parallel streams focussed on three key aspects of Smart Infrastructure and Construction:

\section{Sensors and data analysis}

Recent innovations in sensor systems and development of new data analysis methods allow us to better understand the engineering performance of our infrastructure. Papers in this theme cover new developments in fibre optic sensing, wireless sensor networks and miniature low-power sensors, case studies using innovative sensor systems, and progress in data analysis methods. The findings from the work presented in the papers will lead to improvements in performance-based design, more efficient construction and a better-informed maintenance strategy.

\section{Asset management}

Smart sensing technologies offer immense potential to deliver a step-change in whole-life cost and value of infrastructure. Using the data generated by emerging technologies to make effective asset management decisions is critical for ensuring long-term value and sustainability of infrastructure. Papers in this theme discuss the short and long-term challenges in managing infrastructure, innovative models and tools for supporting investment and maintenance decisions, and how BIM can be used as an effective tool for asset management. Through an excellent collection of case studies, this theme offers insights into how the long-term resilience of infrastructure can be improved.

\section{Cities and urban infrastructure}

New technology and business models are emerging in urban infrastructure and service provision. Papers in this theme reveal new insights into the changing roles of infrastructure planning and construction in enhancing resilience and adaptability of the urban environment. Highlights include how new forms of data are transforming our understanding and management of infrastructure and development in cities. Papers from leading scholars and practitioners from engineering, geography, planning, urban design and architecture identify fresh opportunities for interdisciplinary engagement, with ideas for developing all-round and integrated solutions.

Professor Lord Mair, CBE FREng FRS, Sir Kirby Laing Professor of Civil Engineering 